\title{
Az okos hotelekhez kapcsolódó attitűdöket befolyásoló tényezők nyomában: fókuszban a Z generáció
}

\section{Factors influencing attitudes related to smart hotels: Focus on Generation Z}

\author{
Szerzők: Cserdi Zsófia' - Kenesei Zsófia
}

\begin{abstract}
Az utóbbi évek trendjeinek tükrében a hotelek számára létszükségletté vált a technológia szolgáltatási folyamatba illesztése. Óriási különbségek lehetnek azonban az alkalmazott technológiai megoldások szintjében, mely megoldások eltérő módon ugyan, de átveszik a személyes kiszolgálás szerepét egy hagyományosan interakció-központú területen. A jelenség új vetületeként, a koronavírusjárvány okozta krízis következtében, az emberi kontaktus csökkentése és a szállóvendégek megnyugtatása érdekében még erőteljesebben jelentkezhet az okos szolgáltatások, ezzel együtt az érintésmentes technológiák bevezetése iránti igény a turisztikai szolgáltatók felé (QIANTING et al. 2021). Kutatásunkban ennek megfelelően a technológiát magas szinten alkalmazó okos hotelek iránti attitűdöt befolyásoló tényezőket vettük górcső alá, melyeket kvalitatív és kvantitatív elemeket egyaránt felvonultató tartalomelemzés segítségével vizsgáltunk a jövőbeni turisztikai kereslet potenciális megtestesítői, a Z generáció körében.
\end{abstract}

For hotels, the integration of technology into the service process has become a necessity considering the trends of recent years. However, there can be huge differences in the level of applied technological solutions in hotels, which can take over the role of personal service in a traditionally interaction-based sector. As a direct consequence of the phenomenon, due to the crisis caused by the coronavirus pandemic, to reduce human contact and reassure hotel guests, there may be an even greater need for smart services, including touchless technologies (QIANTING et al. 2021). Accordingly, in our research, we examined factors influencing attitudes towards smart hotels using high-level technologies. Content analysis was carried out using both qualitative and quantitative elements among the potential representatives of Generation Z's future tourism demand.

Kulcsszavak: okos hotel, okos szolgáltatások, érintésmentes technológiák.

Keywords: smart hotel, smart services, touchless technologies.

\section{Bevezetés}

A turisztikai ágazat komoly változásokon megy keresztül a technológia folyamatos fejlódése révén (BUHALIS-LAW 2008). Bár az újabb eszközök használata számos esetben hatékonysági előnyökkel jár a vállalatok számára, bevezetésük sikeressé- ge minden esetben függ a fogyasztók elfogadásától. A különbözố technológiai eszközök megváltoztatják a szolgáltatási folyamatokat, melyekhez a szolgáltatóknak ugyanúgy alkalmazkodniuk kell, mint a felhasználóknak. A turizmusban a technikai vívmányok alkalmazása gyakran irányul adott szolgáltatási folyamat kiváltására, mellyel a fogyasztó alkalmazotti hozzájárulás nélkül végezhet el szolgáltatási részfeladatokat. Figyelve a téma szakirodalmát, kiegészítve azt az üzleti gyakorlattal, érdekes folyamatként figyelhetjük az automatizáció különböző szintjeinek elfogadását. Egy reptéren

PhD-hallgató, Budapesti Corvinus Egyetem, zsofia.cserdi@uni-corvinus.hu

2 egyetemi tanár, Budapesti Corvinus Egyetem, zsofia.kenesei@uni-corvinus.hu 
teljesen megszokottnak érezzük, hogy okostelefonunkon keresztül tudunk becsekkolni és egy szállodában sem jelent újdonságot, ha egy önkiszolgáló kioszkon kell be- vagy kijelentkeznünk. Míg az önkiszolgálás ezen formái már kivívták a fogyasztók elfogadását, a különböző okos megoldások, robotizált szolgáltatásfolyamatok relatíve újdonságként hatnak az üzleti gyakorlatban (WIRTZ et al. 2018).

A hotelek számára a technológia szolgáltatási folyamatba illesztése létszükségletként jelenik meg az utóbbi évek trendjeinek tükrében (SMART HOTEL TECHNOLOGY GUIDE 2019). Egyfelól a fogyasztók számára a mindennapi élet részévé vált a digitális technológiák használata, másfelól hozzászoktak az egyéb területeken tapasztalható automatizációhoz, a mesterséges intelligenciához (például chatbotok, augmented reality / kiterjesztett valóság/ eszközök), ami miatt utazásaik során elvárják a zökkenőmentes, magas fokú, személyre szabott élményt. Az okos szolgáltatások használata a hotelszektorban a trendekhez való alkalmazkodás szükséglete mellett a versenyképesség megórzését is szolgálja. A turisztikai iparág szolgáltatói oldaláról a növekvő munkaerőköltségek, valamint a jövőbeni munkaerőhiány szintén ösztönzőleg hatnak a technológiai újítások adaptációjához (IVANOV et al. 2017). Ráadásul a jelenlegi koronavírus-járvány okozta krízis következtében az emberi kontaktusok számának csökkentése és a szállóvendégek megnyugtatása érdekében még erősebben jelentkezhet az okos szolgáltatások bevezetése iránti igény a turisztikai szolgáltatók felé (QIANTING et al. 2021).

A technológia magas szintû́ alkalmazása egy hagyományosan interakció-központú területen, átvéve ezzel a személyes kiszolgálás szerepét, rendkívül érdekes ellentmondást szül a szektorban. Ezért tartjuk relevánsnak a jövóbeni szállodai szolgáltatás iránt potenciálisan érdeklódő szegmens okos szálloda iránti attitúdjének vizsgálatát. $A$ választott $Z$ generáció (digitális bennszülöttek) ugyanis jelentős fizetőképes kereslettel fog megjelenni a turisztikai szolgáltatások piacán a következő években. McCRINDLE (2012) a Z generációba az 1995 és 2010 között születetteket sorolja, ugyanakkor a határvonal nem ilyen éles, természetesen léteznek generációk közti átmenetek. A digitális bennszülöttek közös tulajdonságaként kiemelendô, hogy már gyerekkorukban hozzászoktak a digitális technológiák használatához, az azokhoz való adaptációban szocializálódtak (TURNER 2015). Mindez pozitívan befolyásolhatja a csoport okos hotelekben történő technológiahasználathoz kapcsolódó attitúdjeit. KULCSÁR és GROTTE (2018) a szállodai tartózkodás során értéket jelentó tényezók feltárásakor a Z és az Y generációk össze- hasonlításánál felhívták a figyelmet arra, hogy a szállodai menedzsmentdöntéseknek és marketingtevékenységnek mindig a különböző szegmensek igényeihez kell alkalmazkodnia. Kutatási kérdésünk tehát a következő: Milyen tényezők befolyásolják a $Z$ generáció okos hotellel szembeni attitúdjét?

\section{Okos hotelek vs technológia alkalmazása a szállodai kiszolgálásban}

Az okos hotel (angolul: smart hotel) kifejezést a gyakorlatban olyan intelligens szállodák esetén alkalmazzuk, melyek operatív múködésében számos információs technológia együttmúködésével valósul meg a szállóvendégek kiszolgálása. A technológia segítségével nem csupán a vendégek szállodán belüli tartózkodását könnyíthetik meg, hanem adott desztinációban támogathatják a teljes nyaralási folyamatot (LAI-HUNG 2017, WUCHENG 2018). Mindazonáltal WU és CHENG (2018) felhívja a figyelmet arra, hogy az okos hotel kifejezés nem egy akadémiai fogalom, sokkal inkább egy gyakorlatban használt üzleti modell, ami a hotelek azon új generációját hivatott jelölni, melyek magas szinten alkalmazzák múködésükben a technológiai újításokat. A gyakorlati definícióval kapcsolatban problémaként merülhet fel, hogy nincs sem nemzetközileg, sem nemzeti szinten érvényes hivatalos sztenderd arra vonatkozólag, hogy a technológiahasználat mely szintje szükséges egy szállodánál ahhoz, hogy azt okos hotelnek lehessen nevezni. Ugyanakkor a szakirodalom azt mutatja, hogy az okos hoteleket alapvetően a szolgáltatások automatizációjára, ezzel együtt a hatékonyság növelésére tervezték, többek közt különbözó csúcstechnológiák (úgy, mint mesterséges intelligencia, digitális eszközök, információs technológia, robotok) szolgáltatási folyamatba történő integrálásával (KIM-HAN 2020).

Szállodai környezetben többféle módon jelenhetnek meg, például robot kiszolgáló személyzet (recepción, hotel éttermében, conscierge pultnál), chatbotok vagy önkiszolgáló eszközök (be- és kijelentkezó kioszkok, tabletek, okostelefonos applikáció) formájában. KABADAYI és szerzótársai (2019) szerint egy okos szálloda olyan intelligens szolgáltatásokat nyújt, melyekben a különböző fejlett technológiák együttmúködése, egyfajta szisztematikus adatgyújtéssel kiegészülve, már lehetôvé teszi a fogyasztók (ebben az esetben a szállóvendégek) igényeinek előrejelzését, mindemellett képesek alkalmazkodni a váratlan szituációkhoz és a környezetben bekövetkezó változásokhoz. Ebben a megfontolásban a technológia több formájának integrált múködése a vendégek igényei alapján sze- 
mélyre szabott élményt eredményez. Így az okos eszközök használatát összekötik az okos szolgáltatások (smart services) nyújtásával, ami már inkább fogyasztócentrikus megközelítés, mint a korábbi szolgáltatóközpontú meghatározások.

AJZEN és FISHBEIN (1980) átgondolt cselekvés elmélete alapján, melyet a technológiaelfogadás alapmodellje $\left(\mathrm{TAM}^{3}\right)$ is átvett, egy okos hotel gyakorlati kipróbálását minden esetben meg kell előznie a használati szándéknak, melyet a hozzá kapcsolódó attitúdök határoznak meg. Az attitúdöt befolyásoló tényezők vizsgálata tehát hozzájárulhat az ismert és sokat használt technológiaelfogadási modellek (TAM és UTAUT ${ }^{4}$ különbözó verzióinak) kiterjesztéséhez.

\section{A kutatás módszertana}

Primer kutatásunk során strukturált online kérdốves megkérdezést alkalmaztunk a Budapesti Corvinus Egyetem Gazdálkodástudományi Karának elsóéves hallgatói körében, véletlen mintavételi gyakorlatot használva. A kérdốiv 2020.05.05-tól 2020.05.26-ig volt elérhető, melyre összesen 345 kitöltés érkezett. A kérdőív utazási és okostelefon-használati szokásokhoz kapcsolódó témaköröket tartalmazott, illetve bemutatta számukra az okos hotel koncepciót egy létezó okos szálloda paramétereinek leírásával és booking. com-os manipulált illusztráció megjelenítésével. A kontextus ebben az esetben egy, a magyar fogyasztók számára kelló újdonságértékkel rendelkező, okostelefonos applikációval múködtethetó szállodát jelentett, ahol nincs lehetőség a személyes interakcióra az alkalmazottakkal (kivéve az operatív személyzetet, például takarítást, szerelést végzó alkalmazottak). A hozzá kapcsolódó attitúdöket, a válaszadók elsố reakcióit 3 nyitott kérdéssel tártuk fel. Szứrőkérdéseink, valamint adattisztítás után (többek közt a nyitott kérdésekre adott válaszok mélysége, a Z generációba tartozás ellenőrzése) 256 kitöltés került végső elemzésre. A válaszadók demográfiai adatait tekintve a nők voltak többségben, arányuk $60,9 \%(n=156)$ volt a mintában. Életkor vonatkozásában a 20 évesek aránya volt kiemelkedó $43 \%$-os megoszlással $(\mathrm{n}=110)$, óket követte sorban a 19 éves $(32,4 \%$; $n=83)$, a 21 éves $(16,8 \% ; n=43)$, majd a 22 éves korosztály $(4,3 \% ; n=11)$. A 18 , illetve a $23-25$ év közötti korosztály évenkénti bontásban egyenként már nem érte el a 2\%-ot, arányuk összesen $3,5 \%(n=9)$. Az utazási szokásokat tekintve jövőbeli potenciális utazókról beszélhetünk, hiszen a koronavírus-járvány előtti időszakban többségük évente átlagosan 2-3 alkalommal utazott belföldi vagy külföldi helyszínekre (59\%; n=151), sőt 4-szer vagy annál többször 31,2\%-uk $(n=80)$. Az évi egyszeri utazást 9,8\%-uk $(n=25)$ jelölte meg.

A minta alkalmasnak bizonyult a válaszok kvalitatív és kvantitatív tartalomelemzésére. A tartalomelemzést minden esetben az írott szöveg többszöri átolvasásával, az általános jelentés megértésével kell kezdeni, majd az iteratív kódolási folyamat segítségével részletekbe menó elemzést kell végezni. A kódolási folyamat lényege, hogy a szöveget kategóriákra osztjuk, elnevezzük, majd ezek előfordulását vizsgáljuk és értelmezzük a teljes írott anyagon, ügyelve arra, hogy folyamatosan reflektáljunk az új jelentéstartalmakra (CRESWELL - CRESWELL, 2017). A folyamat az eredmények interpretálásával zárul. A kvantitatív tartalomelemzés esetünkben csupán a gyakorisági sorok ismertetésekor fog megjelenni, a fố hangsúly a kvalitatív, tartalmi elemzésen lesz.

\section{Kutatási eredmények és következtetések}

A kódolási folyamat eredményeként kódcsaládokat kaptunk, melyek fő csomópontjait, kategóriáit elméleti modellbe rendeztük (1. ábra).

A nagyszámú minta lehetóvé tette a kvalitatív tartalomelemzést követôen kapott tényezók kvantitatív összesítését. A kategóriák elnevezései, azon belül is a kódcsoportok rendezése rendkívül szubjektív kutatói feladat. Összesen 1033 kódot jelöltünk meg.

\subsection{OKOS HOTELLEL SZEMBENI ATTITÜDÖT POZITÍVAN BEFOLYÁSOLÓ TÉNYEZÖK}

A válaszadók összesen 520 alkalommal jelöltek meg olyan aspektusokat, melyek miatt véleményük szerint vonzó lehet egy okostelefonos applikációval múköőő hotelben történő tartózkodás. Az okoshotellel szembeni attitúdjüket, ezzel együtt a kipróbálási szándékot Támogató tényezóket, a válaszok alapján összesen 4 fő kategóriába rendeztük, melyek számos alcsoportot tartalmaznak.

\subsubsection{Technológiai jellemzők}

A legnépesebb kódcsaládot a Technológiai jellemzók alkotják, mely 5 alkategóriát megjelenítve 390 kódot tartalmaz. A technológiai jellemzók közül a válaszadók szerint az applikációval helyettesített szolgáltatási folyamat legmeghatározóbb elónye az Idômegtakarítás (155), mely egyfelól vonatkozik a gyorsabb ügyintézésre, másfelól a szállodai fo-

\footnotetext{
3 Technology Acceptance Models

${ }^{4}$ Unified Theory of Acceptance and Use of Technology
} 
Okos hotellel szembeni attitúdöt befolyásoló tényezók

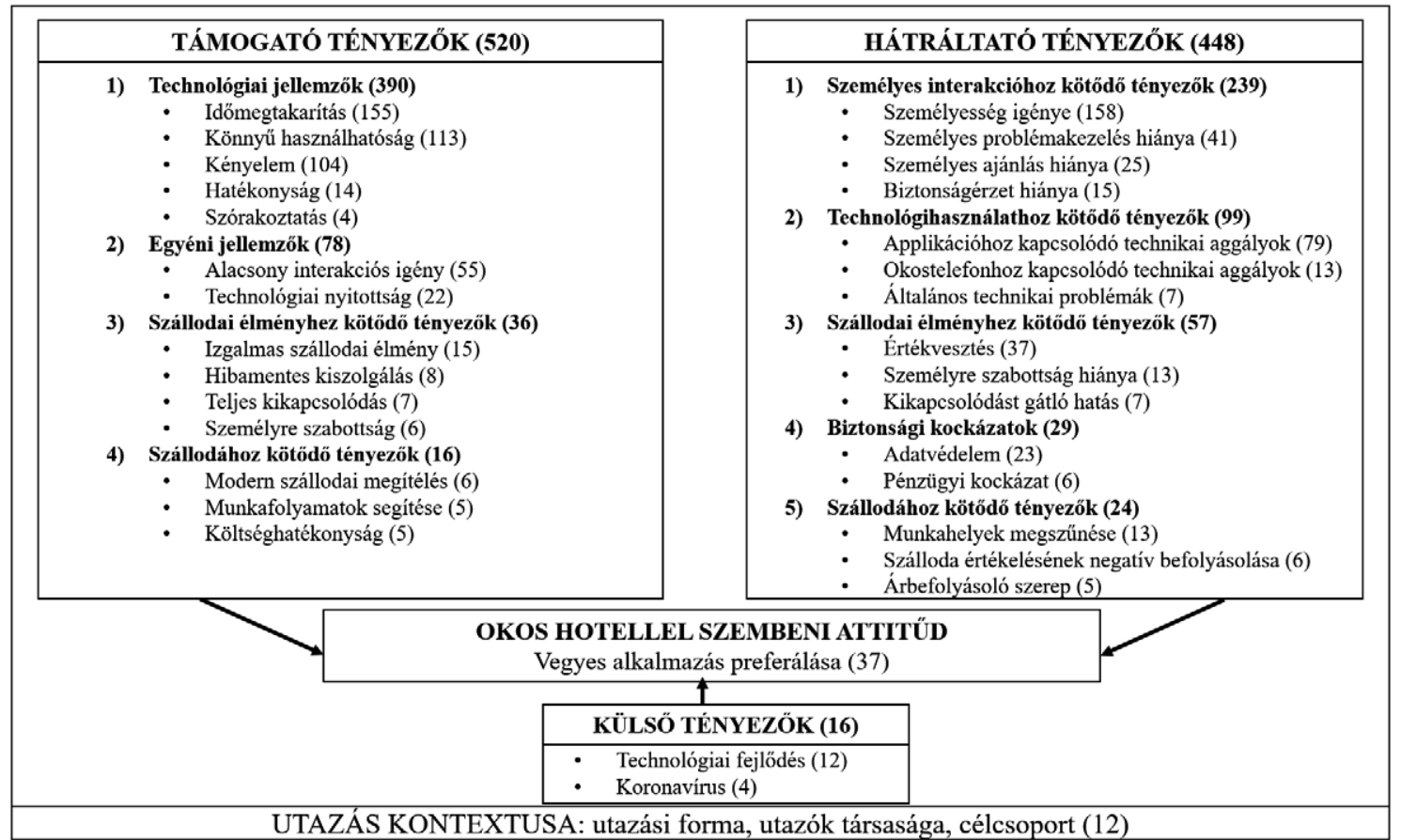

Forrás: saját szerkesztés

lyamatok során korábban tapasztalt várakozási idő megszúnésére és a sorban állás kiküszöbölésére.

„Sokkal kevesebb idôt venne igénybe, mint a személyes kiszolgálás, hiszen nem kellene várnunk a sorunkra, egyszerre többen is becsekkolhatnának, és használhatnák a szolgáltatásokat."

A válaszadók 113 alkalommal tettek utalást az applikáció Könnyú használhatóságára. A könnyú használat sok esetben a hagyományos szolgáltatási formával összehasonlítva lett meghatározva, például az ügyintézés megkönnyítése, a félreértések elkerülése és a közvetlen ügyintézés által. Ebbe a kategóriába kódoltuk továbbá a gördülékenyebb, egyszerúbb, rugalmasabb ügyintézést, melyek a válaszadók véleménye szerint a szállodai tartózkodást is megkönnyítik. Megjelent továbbá a nyelvi akadályok leküzdésének lehetôsége is, ami szintén a tartózkodást könnyítik meg az utazók számára.

"Azért lenne vonzó, mert sokkal egyszerúbben el tudnék végezni olyan dolgokat, amikhez a szállodai személyzetnek nincs köze, meg sem kell jelenni a lobbyban."

Harmadik alcsoportként a Kényelem kategória (104) jeleníti meg az applikáció praktikus voltát, hogy akár a szobából is elintézhetővé válnak különböző szolgáltatói folyamatok. Az applikáció ráadásul bárhol és bármikor a vendégek rendelkezésére áll, a vendég mindent egy helyen találhat meg (az igényeiknek megfelelően sokszínú funkciókat, információkat), továbbá eltúnik a szobakulcs elhagyásának lehetősége.

„Akár a szobából is el tudnék intézni aktuálisan felmerülő problémákat, anélkül, hogy le kellene mennem a recepcióra, vagy akár csak fel kellene kelnem az ágyból a telefonhoz."

A technológiai jellemzők között kevesebb említést kapott ugyan, de megjelent az applikáció konkrét Hatékonysága (14), valamint használatának Szórakoztató (4) volta.

\subsubsection{Egyéni jellemzők}

Az attitúdöt pozitívan befolyásoló tényezők következó nagy csoportja az Egyéni jellemzók (78), mely kategóriában a tartalomelemzés során megjelenő 2 csomópont remekül igazodik a minta $Z$ generációs mivoltához. Elsőként az Alacsony interakciós igényt (55) említjük, melyre közvetlenül és közvetett módon egyaránt utaltak a válaszadók. Többek közt negatív tapasztalataikat fejezték ki a személyzettel való kommunikációval kapcsolatosan, melynek kellemet- 
lenségeit, fáradalmait az applikáció kiküszöbölheti. Számos esetben negatívan élik meg, ha minden apróság miatt a személyzetet kell mozgósítaniuk, miközben egy okostelefonos applikáció használatával a teljes magánszféra elónyeit élvezhetnék.

„Öszintén szólva számomra inkább kellemetlenek a személyzettel való interakciók, mint kellemesek. Jobban szeretek a társaságommal lenni, és egy ilyen applikáció minimalizálná a személyzettel való kellemetlen kommunikációt."

Második egyéni jellemzőként a Technológiai nyitottságot (22) jelöltük, mely csomópontba tartozó kódok többek közt az applikáció újdonságértékét méltatták. A válaszadók szeretnek technológiai újdonságokat kipróbálni, szeretik az okostelefonon keresztül történő ügyintézést.

"A technológiai újitások mindig is érdekeltek, ezért kíváncsi lennék, milyen is ez a gyakorlatban."

\subsubsection{Szállodai élményhez kötődő tényezők}

Harmadik fố csoportunk a támogató tényezók között a Szállodai élményhez kötódô aspektusok (36). Bár az alkategóriák kevesebb említéssel bírnak, 4 csomópontot el tudtunk különíteni. Elsóként az Izgalmas szállodai élményt (15), mely szerint az okos hotelekben a technológiahasználat érdekessé, izgalmassá teheti a szállodai tartózkodást.

„Teljesen új megközelítést adna a szállodai élménynek, új impulzusok érhetnek, valamint egy modern jövőbe tekintô megvalósitást tükröz, amit mindenképp kipróbálnék."

Megjelent a Hibamentes kiszolgálás (8) szempontja is, ami a válaszadók szerint az emberi tényező kiküszöbölése miatt lenne vonzó, valamint kiszứrhetôvé válna a szolgáltatásminőség ingadozása. Külön kategóriába soroltuk a Teljes kikapcsolódás (7) gondolatkörét, mely szerint az alkalmazottak kizárása a folyamatból sokkal nyugodtabb pihenést eredményezne, összességében többet lehetne kihozni a nyaralásból. Negyedik csomópontként a Személyre szabottság (6) mutatkozott, ami a közvetlen említések mellett az igényeknek megfelelô szolgáltatás nyújtásaként jelent meg.

\subsubsection{Szállodához kötődő tényezők}

Utolsó támogató tényezőcsoportunk a Szállodához kötődô tényezók kategóriája (16), 3 csomóponttal.
Elsőként a Modern szállodai megitélés (6) kategóriát alkottuk meg a kódok alapján. A válaszadók véleménye szerint egy okos hotel modernséget, fejlettséget, 21. századi képet sugároz. Megjelent a Munkafolyamatok segitésének (5) gondolata, miszerint a mobilapplikációval a szállodai háttérfolyamatok is könnyebben menedzselhetôvé válnak. Végül a Költséghatékonyság (5) kategóriát hoztuk létre a válaszok alapján. A vélemények szerint egy okos hotelben való tartózkodás olcsóbb a szállodának, emiatt a fogyasztónak is.

\subsection{AZ OKOS HOTELLEL SZEMBENI ATTITÜDÖT NEGATÍVAN BEFOLYÁSOLÓ TÉNYEZŐK}

Az okos hotelek kipróbálását Hátráltató aspektusokat a válaszadók összesen 448 alkalommal említettek. Válaszaik alapján 5 fó kategóriát különítettünk el, melyek az előnyökhöz hasonlóan számos alcsoporttal rendelkeznek.

\subsubsection{Személyes interakcióhoz kötődő tényezők}

A negatív töltetú kódok több, mint fele kapcsolódik a Személyes interakcióhoz (239), ami az elsô csoportunk a kategóriában, és 4 csomópontot tartalmaz. Elsóként a Személyesség igénye (158) kategóriát tárgyaljuk, mely számos elágazást hordoz. Többek közt megjelenik benne a személyes kommunikáció és kontaktus igénye a szállodai környezetben, a személyes ügyintézés biztosabb volta és a személyzet nélküli szálloda rendkívül negatív víziója.

"Szeretem azt, amikor a hallba belépve hangosan köszönünk és egymásra mosolygunk a recepcióssal, nekem hiányoznának a személyes kapcsolatok, kis találkozások egy hotelből."

Alkategóriaként jelöltük továbbá a Problémakezelést (41), mely ebben az összefüggésben egy okos hotelnél bármilyen probléma, hiba, panasz esetén az alkalmazottak hiányához kötődő aggodalmat jeleníti meg.
„Bármi problémám lenne, ami különleges bánás- módot igényel, akkor nem tudnék kihez fordul- ni, mert az applikáció például nem készülhet fel minden eshetôségre, balesetre."

A Személyes ajánlás hiánya (25) szintén igen negatívan hatott, hiszen számos esetben jelezték a válaszadók, mennyire szeretik, ha alkalmazottaktól kaphatnak személyes ajánlásokat akár a helyi, akár a szállodai ételekrôl, látnivalókról, kulturális programokról legyen szó. 
"Fontosnak tartanám a személyzet személyes jelenlétét, sokszor érdekelne a véleményük a programokról, valamint a személyes ajánlatok, amiket szívesebben fogadok el egy embertól, mint egy applikációtól."

Az alkalmazottakra vonatkozóan problémaként rajzolódott ki a Biztonságérzet hiánya (15), hisz mind jelenlétük megnyugtató, mind hiányuk frusztráló volta, illetve a közvetlen visszajelzés megszúnése aggodalmat szült a válaszadókban.

\subsubsection{Technológiahasználathoz kötődő tényezők}

Második fő kategóriánkba a Technológiahasználathoz kötôdô (99) tényezóket soroltuk. A kategória 3 csomópontja közül kiemelkednek az Applikációhoz kapcsolódó technikai aggályok (79), melyben a válaszadók különböző konkrét múködési kérdéseket vetettek fel, a használathoz kapcsolódó dilemmákat fogalmaztak meg. Az applikáció mellett megjelentek az Okostelefonhoz kapcsolódó technikai aggályok (13) is, melyben a memória foglalásától a saját adatforgalom használatán át a telefon lemerülésének opciójáig számos eset fordult eló. Általános technikai problémaként (7) kezeltük az okostelefonhoz vagy az applikációhoz konkrétan nem köthető megjegyzéseket (például felesleges technológiai újítás, csak egy újabb önkiszolgáló opció stb.)

\subsubsection{Szállodai élményhez kötődő tényezők}

Harmadik fô kategóriaként a Szállodai élményhez kapcsolódó tényezók (57) jelentek meg attitúdöt befolyásoló aspektusokként, ezúttal negatív értelemben, 3 csomóponttal. Elsóként az Ertékvesztés (37) kategóriát emeljük ki, mely tömöríti azokat a konkrét véleményeket, melyek szerint egy okos hotel esetén sérül a szállodai élmény, félreértések zavarhatják meg a pihenést vagy magasabb lehet a kiegészítő szolgáltatások foglaltsága.

„Egy szállodában igénylem a személyes kontaktust a személyzettel és a mobilapplikációk használatával rideg, monoton lenne a szállodai ügyintézés. Az üdülés részének tartom a személyes kiszolgálást, szerintem sokat hozzáad a szállodában szerzett élményeimhez."

A Személyre szabottság (13) szintén az alkalmazottak hiányából fakadt azoknál a válaszadóknál, akik szerint ók jelentik a valódi személyre szabottság lehetőségét, hisz ôk tudják kezelni a speciális kéréseket, igényeket. A válaszadók szerint a technológia túlzott alkalmazása Kikapcsolódást gátló hatással
(7) is bír a szállodában, ráadásul nó általa a vendég saját felelőssége.

\subsubsection{Biztonsági kockázatok}

Negyedik fő kategóriánk a Biztonsági kockázatok (29) nevet kapta, melyben az Adatvédelem (23) témakörben többek közt a személyes adatok védelme, a felesleges hírlevelek és reklámanyagok elkerülésének igénye jelent meg.

„A személyes adatkezelés miatt vannak aggályaim kicsit, valószinüleg hónapokig hasonló reklámok jelennének meg a böngészömben, hírleveleket is küldhetnek, ami nagy mennyiségben idegesitô."

Továbbá a Pénzügyi kockázat (6) kategóriában a telefonos fizetéssel kapcsolatos negatív érzéseiket fogalmazták meg.

„Az online vásárlásokkor általában aggodalmaskodás nélkül fizetek, azonban egy szállodánál nagyobb összeg kifizetését inkább intézem személyesen, számomra megnyugtatóbb, ha a recepcióstól hallom, hogy minden rendben, mintha azt egy applikáción keresztül látnám."

\subsubsection{Szállodához kötődő tényezők}

Ötödik kategóriaként a Szállodához kötôdô tényezók (24) jelennek meg, ami 3 csomópontot tartalmaz. A kategóriában negatív tényezóként jelent meg a Munkahelyek megszúnése (13), a Szálloda értékelésének negatív befolyásolása (6) az imázson, valamint a negatívabb minőségészlelésen keresztül. Továbbá megjelent az Árbefolyásoló szerep (5), ugyanis a vélemények szerint az okos hotel koncepció növelheti az árakat, melyet nem szándékoznak megfizetni.

\subsection{AZ OKOS HOTELLEL SZEMBENI ATTITÜDÖT BEFOLYÁSOLÓ KÜLSÖ ÉS KONTEXTUSFÜGGÖ TÉNYEZÖK}

Fontos eredményként tartjuk számon, hogy a válaszadók 37 alkalommal jelezték, hogy egy okostelefonos szállodai applikációt a személyzettel vegyes kiszolgálási formában vennének igénybe. Az applikáció alkalmazását a kiegészító szolgáltatási funkciók igénybevételekor preferálnák, opcionális lehetőségként.

„Számomra a személyes jelenlét megmaradása lenne ideális, ezt egészíthetné ki, illetve gyorsíthatná, hogy opcionálisan az applikáción keresztül is történhet az ügyintézés." 
Külső befolyásoló tényezőként (16), illetve a Technológiai fejlódés részeként (12) evidensnek gondolták a válaszadók, hogy a technológia egyre inkább a szállodai kiszolgálás részévé válik, ez a jövő. A kijelentés negatív és pozitív értékítélettel egyaránt megjelent.

„Véleményem szerint ez a fajta innováció a jövôben szélesebb körökben el fog terjedni, egyre több szálloda és szállodalánc fogja használni."

Említették továbbá a Koronavírus (4) valószínúsíthetően támogató szerepét a szállodai technológiai újítások elterjedésében, így csökkentve a fogyasztói kockázatokat.

\begin{abstract}
"Érdekesnek találom a témát, mivel egy olyan iparágat érint, ahol tradicionálisan fontos szerep jutott a fogyasztóval történó interakciónak. A koronavírus, illetve a digitalizáció hatásai miatt ez egyre kényelmetlenebb a vendégeknek, igy biztos vagyok benne, hogy a megfelelö és könnyen kezelhetô applikációk használatával ez a szolgáltatás hamar elterjed belföldi és külföldi hotelekben egyaránt."
\end{abstract}

Mindemellett fontos kiemelni, hogy az attitúdöket, és azokkal együtt a használati szándékot, az Utazás kontextusában (14) érdemes elemezni, hiszen az utazási formát tekintve a szabadidôs utazókkal ellentétben az üzleti utazók számára előnyös lehet egy okos hotel.

„Számomra ebben az esetben fontos az utazás célja. Magánjellegú utaknál, ahol a kikapcsolódás és az élmény a fontos, egyértelmüen a személyes kiszolgálást preferálom, mivel ilyenkor jó letenni a telefont és pihenni, ha telefonon kellene intézni a hotellel kapcsolatos teendőket óhatatlanul jönnének a munkával, tanulással kapcsolatos üzenetek, és ez megnehezítené, hogy jól érezzem magam. Üzleti úton, ahol fontos a gyors elérés és könnyü ügyintézés, úgyis használom a telefonom, ekkor jó ötletnek tartom az applikációt."

Tovább boncolva az utazás kontextusát, a válaszadók szerint az utazók társasága is meghatározó lehet az okos hotellel kapcsolatos attitúdök tekintetében. Míg egyedüli utazóként praktikus lehet a használata, addig családi kikapcsolódás esetén kevésbé.

„Mikor elutazom akkor a családommal, barátaimmal szeretnék kikapcsolódni és az utolsó, amit a kezembe szeretnék venni, az okostelefonom.
Eltereli könnyen a figyelmet a jelenról és rengeteget használjuk így is különbözô dolgokra. Nem szívesen használnám még szállodákban is."

Az utazók életkor szerinti megkülönböztetését is említették a válaszadók. Több esetben nyilatkoztak az idôsebb korosztály számára nehézkes, kényelmetlen applikációhasználatról, míg a fiatalabb generáció esetében az okos hotel koncepció valószínúsíthetô sikerét méltatták.

„Véleményem szerint korosztályfüggő egy ilyen hotel sikere. A fiataloknak valószinúleg tetszene, de a 40+-osok sokkal inkább szeretik a személyes kontaktust, és az app-okat sem tudják kifogástalanul használni."

\section{5. Összegzés}

Az utóbbi évek szállodai gyakorlatát tekintve látható, hogy a hagyományos szállodaláncok (a személyes kiszolgálást kiemelkedő értékként kezelő, nem technológiai újításokra pozicionált láncok) is a technológiai újításokkal lépést tartva folyamatosan építik be szolgáltatási folyamataikba az okos megoldásokat. Ugyanakkor a szállodai gyakorlatban a technológia ezzel átveszi a személyes kiszolgálás szerepét, ami teljes mértékben átalakíthatja ezt a tradicionálisan emberi interakciókra épító iparágat. Tanulmányunkban kíváncsiak voltunk arra, hogy a technológiai újításokat magas szinten alkalmazó szállodai koncepció vajon menynyire képes megszólítani azt a generációt, mely alapjellemzőit tekintve egyik fó támogatója lehet a jövőben a technológia szolgáltatási folyamatba illesztésének a szállodai iparágban, miközben hamarosan jelentős fizetőképes kereslettel fog megjelenni a turisztikai szolgáltatások piacán. Kutatási kérdésünk megválaszolására, miszerint: „Milyen tényezók befolyásolják a Z generáció okos hotellel szembeni attitúdjeit?", strukturált online kérdóíves megkérdezést alkalmaztunk egyetemi hallgatók körében. A kérdőívben szereplő nyitott kérdésekre adott válaszokat kvalitatív és kvantitatív elemeket egyaránt felvonultató tartalomelemzés segítségével vizsgáltuk.

A szakirodalmi kutatás és gyakorlati szállodai példák alapján észrevehetô, hogy bizonyos országokban technológiai szinten és fogyasztói elfogadásban egyaránt előrébb járnak. Míg a Távol-Keleten már nem lepődnek meg a szállodai vendégek azon, ha a recepción egy humanoid robottal találkoznak, addig Magyarországon még az is újdonságnak számít, ha egy szállodában kizárólag okos eszközök segítségével (pl. tablet, okostelefon) lehet bejelentkezni. Ennek megfelelően kell 
adott technológiai szinten vizsgálni az okos szállodai szolgáltatásokat, és ennek tükrében kell kezelni a különböző országokban feltárt technológiaelfogadási eredményeket is, hiszen minden esetben egyfajta kulturális szúrőn keresztül lehet értelmezni a kapott eredményeket. Így választottuk ki kutatási kontextusunkat: egy, a magyar fogyasztók számára kellő újdonságértékkel rendelkező, okostelefonos applikációval igénybe vehetô szállodát, ahol nincs lehetóség a személyes interakcióra az alkalmazottakkal. A kontextus limitáltsága mellett kutatási korlátként jelent meg a válaszok eltérô hoszsza (karakterszámok tekintetében), ugyanakkor a tartalomelemzésünk ennek megfelelő mélységben készült. Eredményeink nem általánosíthatóak a Z generációra, ugyanakkor a Budapesti Corvinus Egyetem Gazdálkodástudományi Karának hallgatói közül véletlen mintavétellel kiválasztott nagyszámú bázis alapján széles körú megállapítások tehetőek.

Eredményeink hasznosak a gyakorlati szakemberek számára, valamint rendelkeznek elméleti hozzáadott értékkel. Szállodai menedzsment implikációként fontos eredmény, hogy a szállodai személyes interakció iránti igény még a Z generációnál sem minden esetben írható fölül, ugyanakkor bizonyos szállodai részfolyamatok elvégzése esetén látnak fantáziát azok technológiával való helyettesítésében. Eredményeink összhangban vannak KABADAYI és szerzótársai (2019) meglátásával, miszerint a feladat semmiképpen sem az emberi személyzet eliminációja, hanem annak megértése fogyasztói oldalról, hogy a vendégek milyen esetekben preferálják az emberi kontaktust a technológiával szemben.

Akadémiai szinten az okos hotelek szakirodalmában az attitúdöt befolyásoló tényezők vizsgálata hozzájárul az ismert és sokat használt technológiaelfogadási modellek (TAM és UTAUT különböző verzióinak) kiterjesztéséhez. Ráadásul esetünkben egy egyébként a technológiára rendkívül nyitott generáció körében ismerhettük meg a koncepciót támogató és gátló tényezőket, különbözô külsô és kontextusfüggô tényezôkre is felhívva a figyelmet. Az okos hotelekhez kapcsolódó fogyasztói attitúdök feltárása a jövôben lehetôséget nyújt további kvantitatív kutatások lefolytatására. Ugyanakkor a jelenlegi helyzetben az egész világra kiterjedő koronavírus-járvány alapjaiban rendezheti át az utazók technológiával kapcsolatos attitúdjét. Jövőbeni kutatás tárgyát képezheti, hogy a vírusveszély miatti kontaktuscsökkentési igény állandó lesz-e az utazói magatartásban, ami erôteljesen támogatná az érintésmentes technológiák szállodai elterjedését.

\section{Köszönetnyilvánítás}

Jelen tanulmány az Európai Unió, Magyarország és az Európai Szociális Alap társfinanszírozása által biztosított forrásból az EFOP3.6.3-VEKOP-16-2017-00007 azonosítószámú „Tehetségból fiatal kutató - A kutatói életpályát támogató tevékenységek a felsőoktatásban" címú projekt keretében jött létre.

\section{Felhasznált irodalom}

AJZEN, I. - FISHBEIN, M. (1980): Understanding Attitudes and Predicting Social Behavior. Englewood Cliffs, NJ: Prentice Hall.

BUHALIS, D. - LAW, R. (2008): Progress in information technology and tourism management: 20 years on and 10 years after the Internet The state of eTourism research. Tourism management. 29(4). pp. 609-623. https://doi.org/10.1016/j.tourman.2008.01.005

IVANOV, S. H. - WEBSTER, C. - BEREZINA, K. (2017): Adoption of robots and service automation by tourism and hospitality companies. Revista Turismo \& Desenvolvimento. 27/28. pp. 1501-1517.

KABADAYI, S. - ALI, F. - CHOI, H. - JOOSTEN, H. - LU, C. (2019): Smart service experience in hospitality and tourism services. Journal of Service Management. https://doi.org/10.1108/JOSM-11-2018-0377

KIM, J. J. - HAN, H. (2020): Hotel of the future: exploring the attributes of a smart hotel adopting a mixed-methods approach. Journal of Travel $\mathcal{E}$ Tourism Marketing. 37(7). pp. 804-822. https://doi.org/10.1080/10548408.2020.1835788

KULCSÁR N. - GROTTE J. (2018): Mit várunk a szállodáktól? - avagy a legmeghatározóbb fogyasztói szegmens számára értéket jelentő tényezók a szállodákban. Turizmus Bulletin. 18(3). pp. 6-16.

DOI: 10.15170/TVT.2021.06.01.06

LAI, W.-C. - HUNG, W.-H. (2017): Constructing the smart hotel architecture - A case study in Taiwan. The 17th International Conference on Electronic Business. ICEB 2017 Proceedings. Dubai, UAE. pp. 4-8.

QIANTING, L. - CHUNG, H. C. - CHUNG, N. (2021): A Study on the Factors Affect the Technology Satisfaction on AI Based Selfservice Technology Service Failure in Hotel. In: Wörndl, W. - Koo, C. - Stienmetz, J. L. (eds): Information and Communication Technologies in Tourism 2021. pp. 123-127. Springer, Cham. https://doi.org/10.1007/978-3-030-65785-7_10

TURNER, A. (2015): Generation Z: Technology 
and social interest. The journal of individual Psychology. 71(2). pp. 103-113.

https://doi.org/10.1353/jip.2015.0021.

WIRTZ, J. - PATTERSON, P. -KUNZ, W. -GRUBER, T. - LU, V. N. - PALUCH, S. - MARTINS, A. (2018): Brave New World: Service Robots in the Frontline. Journal of Service Management. 29(5). pp. 907-931.

https://doi.org/10.1108/JOSM-04-2018-0119

WU, H. C. - CHENG, C. C. (2018): Relationships between technology attachment, experiential relationship quality, experiential risk and experiential sharing intentions in a smart hotel. Journal of Hospitality and Tourism Management.
37. pp. $42-58$.

https://doi.org/10.1016/j.jhtm.2018.09.003

\section{Internetes források}

McCRINDLE, M. (2012): Generations Defined. https://mccrindle.com.au/wp-content/ uploads/2018/03/Generations-DefinedSociologically.pdf, Letöltve: 2021. május 2.

SMART HOTEL TECHNOLOGY GUIDE (2019): Using Technology to Transform the "Heart"-ofHouse, Singapore Hotel Association. https:// sha.org.sg/publications/smart-hoteltechnology-guides, Letöltve: 2021. április 28. 